Routhier, D. D., K. W. Dufour, M. T. Bidwell, and R. Clark. 2020. Habitat occupancy by breeding Pied-billed and Horned Grebes in Prairie Canada: correlates of pond use and breeding success. Avian Conservation and Ecology 15(2):3. https://doi.org/10.5751/ACE-01641-150203

Copyright $(0) 2020$ by the author(s). Published here under license by the Resilience Alliance.

Research Paper

\title{
Habitat occupancy by breeding Pied-billed and Horned Grebes in Prairie Canada: correlates of pond use and breeding success
}

\author{
Daniel D. Routhier ${ }^{1}$, Kevin W. Dufour ${ }^{2}$, Mark T. Bidwell ${ }^{2}$ and Robert Clark ${ }^{3,4}$ \\ ${ }^{1}$ Department of Biology, University of Saskatchewan, Saskatoon, Canada, ${ }^{2}$ Canadian Wildlife Service, ${ }^{3}$ Environment \& Climate \\ Change Canada, ${ }^{4}$ Department of Biology, University of Saskatchewan
}

\begin{abstract}
Incorporating information about habitat use and success of breeding birds contributes to a more complete understanding of their ecology and distribution, and can also inform management strategies for species of conservation concern. We used occupancy data that accounted for imperfect detection from a two-year field study of two territorial waterbird species in southcentral Saskatchewan ( $\mathrm{n}=172$ ponds on seven study sites) to explore correlates of pond use and breeding success. In Pied-billed (Podilymbus podiceps) and Horned (Podiceps auritus) Grebes, breeding habitat occupancy corresponded most closely to pond-specific factors rather than those operating at spatial scales beyond the local wetland basin. Pied-billed Grebes were more likely to occupy wetlands that were larger, had greater shoreline complexity, and had less cropland in the adjacent uplands whereas Horned Grebes were more likely to occupy wetlands with less emergent vegetation. These distinct microhabitat preferences could serve to limit interspecific competition. While there was no observable difference in pond occupancy rates between low and high wetland density landscapes, the latter areas contribute disproportionately more breeding habitat for grebes. Using naïve occupancy estimates, breeding success was similar for Horned ( 0.75 , $\mathrm{SE}=0.06)$ and Pied-billed $(0.67, \mathrm{SE}=0.07)$ Grebes. Ongoing conservation initiatives that protect and restore wetland habitat in areas of the prairie and parkland ecoregions with high densities of semipermanent and permanent wetlands should improve long-term habitat security for breeding grebes, including Horned Grebes.
\end{abstract}

\section{Occupation de l'habitat par les grèbes à bec bigarré et les grèbes esclavons reproducteurs dans la région des Prairies du Canada : corrélations entre l'utilisation des mares et le succès de la reproduction}

RÉSUMÉ. L'intégration des informations concernant l'utilisation de l'habitat et le succès de la reproduction des oiseaux permet de mieux comprendre leur écologie et leur répartition et peut aussi informer des stratégies de gestion des espèces dont la conservation est préoccupante. Nous avons utilisé des données d'occupation qui tenaient compte de la détection imparfaite à partir d'une étude de deux ans sur le terrain portant sur deux espèces d'oiseaux aquatiques territoriaux dans la partie centrale-sud du Saskatchewan $(\mathrm{n}=172$ mares sur sept sites étudiés) pour explorer les corrélations entre l'utilisation des mares et le succès de la reproduction. Chez les grèbes à bec bigarré (Podilymbus podiceps) et les grèbes esclavons (Podiceps auritus), l'occupation de l'habitat de reproduction correspondait au mieux à des facteurs spécifiques aux mares qu'à ceux qui opéraient sur des échelles spatiales au-delà du bassin local des zones humides. Les grèbes à bec bigarré étaient plus susceptibles d'occuper des zones humides, dont la côte présentait une plus grande complexité et où les hautes terres voisines étaient moins cultivées, alors que les grèbes esclavons étaient plus susceptibles d'occuper des zones humides présentant moins de végétation émergente. Ces préférences distinctes pour certains micro-habitats pourraient servir à limiter la concurrence interspécifique. Même si on n'a observé aucune différence notable en termes de taux d'occupation des mares entre les paysages à faible et haute densité de terres humides, ces derniers offrent énormément plus d'habitats de reproduction aux grèbes. En utilisant des estimations d'occupation naïves, le succès de la reproduction était similaire chez le grèbe à bec bigarré $(0,75$, $\mathrm{SE}=0,06)$ et le grève esclavon $(0,67, \mathrm{SE}=0,07)$. Les initiatives de conservation en cours qui protègent et restaurent l'habitat des zones humides dans les régions de la prairie et les écorégions des parcs à forte densité de zones humides semi-permanentes et permanentes devraient permettre d'améliorer la sécurité à long termes des habitats pour les grèbes reproducteurs, y compris les grèbes à bec bigarré.

Key Words: detection probability; habitat use; occupancy probability; Podiceps auritus; Podilymbus podiceps; productivity

\section{INTRODUCTION}

Identifying the processes that influence patterns of habitat use is a central goal in ecology (Krebs 1994) and can help to inform conservation programs. Studies of pond use by Horned (Podiceps auritus) and Pied-billed (Podilymbus podiceps) Grebes indicate that use is positively correlated with pond size, depth, and amount of vegetated area (Fournier and Hines 1999, Naugle et al. 1999, Osnas 2003, Kuczynski et al. 2012). Additionally, wetland features such as vegetation structure may be more important than attributes such as vegetation type. More recently, there has been an increased emphasis on processes that operate at broader spatial scales, such as the characteristics of landscapes where wetlands occur (e.g., Fairbairn and Dinsmore 2001, Tozer et al. 2010, McGarigal et al. 2016, Saunders et al. 2019). Naugle et al. (1999) reported that Pied-billed Grebes select breeding sites based solely on wetland characteristics, but Routhier (2012) and Saunders et al. (2019) indicated that upland landscape composition and wetland density were contributing factors, respectively. 
Furthermore, studies simultaneously examining habitat use by breeding waterbirds and subsequent productivity are rare (Tozer et al. 2010).

Wetlands are typically distributed unevenly as opposed to uniformly or randomly (Ettema and Wardle 2002). Thus, a species' distribution and habitat use are also expected to vary with landscape heterogeneity and other landscape features. Semipermanent and permanent ponds (Stewart and Kantrud 1971) that persist during the brood-rearing season are required by grebes, and highly ephemeral seasonal wetlands are not typically used (Ferguson 1977, Sugden 1977, Sealy 1983, Osnas 2003, Hammell 2017). Multiscale habitat use by marsh birds may be further complicated when territorial species compete for similar resources (Jedlikowski et al. 2016). Nudds (1982) reported that differences in preferred microhabitats served to limit interspecific competition between Horned and Pied-billed Grebes; however, some evidence suggests grebe species have overlapping realized niches in prairie Canada and may compete for high quality habitats (Osnas 2003). The putative speciesspecific hierarchy or sequence of pond use presumes that Piedbilled Grebes are the dominant species and evict Horned Grebes from established territories; this pattern does not occur reciprocally (Osnas 2003).

The Horned Grebe is a species of special concern in Canada (COSEWIC 2009, Government of Canada 2020) and improved understanding of processes that drive habitat use and selection and breeding success is essential for guiding habitat conservation programs (Clark and Shutler 1999, Devries et al. 2018). Higher densities of breeding individuals may reflect more available resources and higher reproductive success, and breeding densities have often been used to infer habitat quality even though density may not always be a reliable indicator of habitat quality (e.g., van Horne 1983, Vickery et al. 1992, Bock and Jones 2004). This disconnect between density and habitat quality may occur when the distribution of individuals among habitats follows an ideal despotic distribution pattern (van Horne 1983). In this case, higher quality habitats are occupied by dominant individuals that force subordinates into suboptimal habitats where survival or reproductive success are lower (Fretwell and Lucas 1969). Additionally, individuals may breed in highly altered landscapes because they are not capable of recognizing and avoiding habitats that result in low reproductive success, i.e., the ecological trap hypothesis (Bock and Jones 2004). Because Horned and Piedbilled Grebes are territorial competitors that nonetheless could co-occur on ponds in highly altered heterogeneous landscapes, it may be unwise to assume that breeding densities provide a reliable indicator of habitat quality. However, if this assumption is valid, then models developed to predict variation in species-specific occupancy of wetlands by breeding adult grebes could be used to infer variation in productivity.

Here, we combine (i) multisurvey occupancy data from a two-year field study of breeding Horned and Pied-billed Grebes over a large geographic area in south-central Saskatchewan with (ii) a robust methodology to explore pond use and breeding success relative to three scales of habitat characteristics: within the pond, adjacent to the pond, i.e., within $100 \mathrm{~m}$ of the wetland basin, and landscape, i.e., wetland density within a $11.5 \mathrm{~km}^{2}$ study site. We predicted that Horned and Pied-billed Grebes would have occupancy probabilities related to distinct habitat variables and that landscapes containing a greater number of ponds would attract grebes at higher rates, while presence of cropped agricultural uplands would reduce pond occupancy rates, as others have shown direct and indirect impacts of altered landscapes on bird communities (e.g., Shutler et al. 2000, Wrubleski and Ross 2011). Additionally, if Pied-billed Grebes force Horned Grebes into suboptimal breeding habitats, we expected to see lower productivity in Horned vs. Pied-billed Grebes.

\section{METHODS}

\section{Study areas}

We surveyed 288 small ( $<3.75$ ha) seasonal, semipermanent, and permanent wetland basins on seven study sites (each $\left.11.5 \mathrm{~km}^{2}\right)$ in southcentral Saskatchewan in 2010 and 2011 (geographic coordinates for the center of each site: N52.14386 ${ }^{\circ} \mathrm{W} 104.79125^{\circ}$; $\mathrm{N} 52.14377^{\circ} \mathrm{W} 105.28958^{\circ}$; N51.64783 ${ }^{\circ} \mathrm{W} 106.09853^{\circ}$; N51.24175

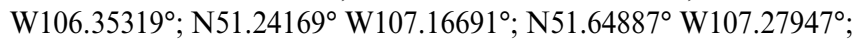
$\mathrm{N} 52.58323^{\circ} \mathrm{W} 108.30762^{\circ}$ ). The seven study sites were selected using historical data from the Waterfowl Breeding Population and Habitat Survey (WBPHS), an annual midcontinent survey conducted jointly by the United States Fish and Wildlife Service and the Canadian Wildlife Service (U.S. Fish and Wildlife Service and Canadian Wildlife Service 1987, Smith 1995). The survey consists of an aerial count of waterfowl, complemented by ground counts to generate visibility correction factors, i.e., to adjust for imperfect detection of birds and ponds from the air. While the WBPHS is designed to monitor waterfowl populations, grebes have been recorded during ground counts in Saskatchewan since 1999 and we used these data to generate a subset of ground survey segments that had relatively high and low grebe counts. Although the WBPHS typically occurs before Horned and Pied-billed Grebes have fully established breeding territories in prairie and parkland Canada and may include some migrants, we assumed that these raw count data, collected over a 12-year period, provide a reliable index of relative grebe distribution in the study area. A stratified random sample of seasonal, semipermanent, and permanent wetlands was then selected for surveys. We detected one breeding Horned Grebe and no breeding Pied-billed Grebes on 116 seasonal ponds surveyed and so removed seasonal ponds from further analyses. The final dataset included 172 semipermanent and permanent ponds (mean $=25$ ponds $/$ study site, range $=13-46$ ). Semipermanent and permanent wetlands were pooled because the focus of the analysis was on quantifiable wetland attributes rather than wetland permanency class. Finally, we detected Red-necked Grebes (Podiceps grisegena) on only 10 (of 172) ponds during all surveys, too few to include in formal analyses; Horned Grebes did not occur on ponds with Red-necked Grebes but there were three instances of co-occurrence with Piedbilled Grebes (Hammell 2017).

\section{Survey methods}

Three breeding surveys were conducted to coincide with peak grebe breeding activity when breeding territories were established (late-May to late-June) and three times during the brood-rearing season (early-July to mid-August), which are consistent with timing reported in other studies (Fournier and Hines 1999, Osnas 2003, Kuczynski et al. 2012). Regular survey intervals and monitoring between the breeding and brood surveys allowed us 
to determine the hatching period for both species in each year, which informed the timing of the brood surveys. The brood survey period also ended prior to chicks becoming flight capable. Known hatch periods also allowed for a post hoc assessment of the breeding surveys given reported incubation timing (Ferguson and Sealy 1983, Otto 1983), and we are confident the surveys closely matched the breeding chronology of both species.

We developed a survey protocol designed specifically for detecting Horned and Pied-billed Grebes during a 4-min call-broadcast survey (Routhier et al. 2014). Pied-billed Grebes often occupy ponds with extensive emergent vegetation cover (Faaborg 1976) and detection probability $(p)$ increases (both visually and aurally) with the use of call-broadcasts for both conspecifics and heterospecifics when compared with passive surveys (Gibbs and Melvin 1993, Conway and Gibbs 2005, Conway and Nadeau 2010). By using a protocol that broadcasts the calls of the subordinate species first, i.e., Horned Grebes (Osnas 2003), we expected $p$ to increase for Horned Grebes where they were present. The sequence of calls based on order of dominance should also increase detection on wetlands where Pied-billed Grebes are present because Pied-billed Grebes are known to displace Horned Grebes. Vocalization probability is highest during a 2-hr period following sunrise (Conway and Gibbs 2005, Conway 2009). To increase the number of ponds surveyed on each study site, surveys commenced shortly after sunrise and were typically completed before 1000 CST. Surveys were conducted during periods of good weather with wind speeds $\leq 20 \mathrm{~km} / \mathrm{hr}$ and precipitation not exceeding a light, intermittent drizzle.

Habitat data collected in the field during the middle surveys for both breeding birds and broods included a visual estimate of the percentage of habitat types (i.e., open water, emergent vegetation, exposed substrate, or woody vegetation) within the pond, and the percentage of upland cover types (i.e., intensive cultivation, grasslands/hayland, pasture, or wooded area) within $100 \mathrm{~m}$ of the wetland edge. A qualitative assessment of the habitat features was collected by two trained observers and cross-comparisons of habitat assignments were conducted to refine estimates. Percentages of each habitat type were rounded to the nearest $20 \%$ to facilitate real-time habitat assessments done in the field. An emergent vegetation index (EVI) was calculated to represent the proportion of emergent vegetation cover within each pond as:

$$
E V I=\frac{B^{e}}{\left(B^{e}+B^{o}\right)}
$$

where, $B^{e}$ and $B^{o}$ represent the proportion of the pond comprising emergent vegetation and open water, respectively.

We determined pond area and perimeter by walking the pond edge, i.e., the wet meadow zone (Stewart and Kantrud 1971) with a handheld GPS (Garmin GPSMAP ${ }^{\circledR} 76 \mathrm{Cx}$ ). The length of the track and the area within the track, i.e., pond perimeter and area, respectively, were calculated using ArcGIS 10 (ESRI 2011). A shoreline complexity index (SCI) was derived to describe the relative shape of each pond as circular (1) or increasingly complex $(>1)$ and was calculated as:

$$
S C I=\frac{B^{\alpha}}{2 *\left(\pi * B^{p}\right)}
$$

where, $B^{a}$ and $B^{p}$ represent the pond area and perimeter, respectively (modified from McGarigal and Marks 1995). We calculated wetland density for each study site based on the number of semipermanent and permanent ponds within each WBPHS ground survey segment and categorized as relatively high (8-15 wetlands $/ \mathrm{km}^{2}$ ) or low $\left(<1-3\right.$ wetlands $\left./ \mathrm{km}^{2}\right)$ wetland density. Of the seven study sites sampled, none contained $4-7$ wetlands $/ \mathrm{km}^{2}$.

\section{Analysis}

Using the "unmarked" package (Fiske and Chandler 2011) in R (R Development Core Team 2014) and a three-occasion encounter history, we constructed candidate sets of a priori models to estimate $p$ and occupancy probability $(\Psi)$ of adults and broods, separately, by species (MacKenzie et al. 2002). We elected not to perform a two-species occupancy analysis because we could not infer the species-specific sequence of occupancy given our sampling frequency, and these species rarely co-occur (details below). Thus, we modeled data for each grebe species in a twostep procedure. First, we constructed a candidate model set to identify important predictor variables for $p$ while holding the structure for $\Psi$ constant. Detection probability was modeled to vary as a function of environmental factors (wind speed, temperature, cloud cover), systematic factors (time of day, survey date, and observer), and biophysical factors (pond area, SCI, and EVI). Importantly, $p$ was modeled to provide unbiased $\Psi$ estimates and improve our assessment of habitat-grebe relationships (MacKenzie et al. 2006). We selected among competing models using Akaike's Information Criterion (AIC) and AIC-based model weights $\left(w_{i}\right)$ (Burnham and Anderson 2002), while $85 \%$ confidence intervals $(\mathrm{CI})$ were used to identify uninformative variables within nested models (Arnold 2010). Covariates in the best-approximating detection model were retained in all candidate models used to estimate $\Psi$.

We constructed a final candidate model set using biologically relevant a priori variables thought to influence breeding grebe occupancy in relation to pond area, SCI, EVI, proportion of upland that is intensive agriculture (hereafter cropland), and wetland density for the study site; correlations among these explanatory variables were low $(\mathrm{r}<|0.30|)$. We also included a year variable to account for underlying variation between years. Model selection, as described above, was used to identify the bestapproximating model(s) (Burnham and Anderson 2002, Arnold 2010). Model-averaging was used to predict $\Psi$ estimates while accounting for model-selection uncertainty, and all models $\leq 2$ AIC units from the best-approximating model are reported regardless of whether uninformative variables were present (Arnold 2010).

We tested whether the relationship between grebe occupancy and EVI was nonlinear, with higher occupancy occurring in ponds with intermediate levels of emergent vegetation, i.e., hemi-marsh, for Pied-billed Grebes and with less emergent vegetation for Horned Grebes. To our knowledge this has not been investigated and would complement previous research that tested for linear relationships. The final candidate set contained models with the linear form of the EVI variable and complementary nonlinear models containing the quadratic term.

Finding and monitoring grebe nests was not feasible given time constraints. Instead, we calculated an index of productivity as the 
proportion of ponds with brood observations relative to those containing breeding pair observations; we did not estimate chick ages or fledging success because of relatively low frequency of visits to ponds and because no grebes were uniquely marked. A subset of 53 semipermanent and permanent ponds was surveyed in both 2010 and 2011 to examine whether presence of a conspecific brood in 2010 was related to presence of breeding pairs in the following year. For these 53 ponds, only the 2010 data were used in the above-described occupancy analyses to avoid pseudoreplication.

\section{RESULTS}

\section{Detection probability}

Overall, detection and occupancy probabilities $( \pm \mathrm{SE})$ were $\hat{p}=$ $0.33 \pm 0.09$ and $\hat{\psi}=0.15 \pm 0.06$ for Pied-billed Grebe, respectively, and $\hat{p}=0.79 \pm 0.04$ and $\hat{\Psi}=0.28 \pm 0.05$ for Horned Grebe. The best-approximating detection models included wetland area and survey date for Pied-billed Grebe, and pond area and time of day for Horned Grebe (Table 1). Pied-billed Grebe $\hat{p}$ increased with wetland area and date while Horned Grebe $\hat{p}$ decreased with wetland area and time of day.

\section{Wetland occupancy probability}

For Horned Grebe occupancy, EVI was the only variable included in the best-approximating model, although considerable model selection uncertainty was evident (Table 2). Model-averaged $\hat{\Psi}$ suggest that Horned Grebe occupancy was highest in open ponds and estimates declined by half as ponds reached $\sim 40 \%$ emergent vegetation cover (Fig. 1A). Other plausible models $(\leq 2 \Delta$ AIC) contained variables with slope coefficient $85 \%$ CIs that overlapped 0, suggesting negligible effects (Arnold 2010). Modelaveraged $\hat{\Psi}$ indicated a slight decline in occupancy as SCI increased (Fig. 1B), but no relationships with pond area or proportion of cropland in adjacent uplands (Figs. 1C and 1D). Wetland density in the surrounding landscape did not influence occupancy for Horned Grebes, as $\hat{\psi}=0.28 \pm 0.04 \mathrm{SE}$ in both low and high wetland density landscapes. There was no evidence that the relationship between EVI and Horned Grebe occupancy was nonlinear or that habitat use was related to land use factors within $100 \mathrm{~m}$ of the wetland.

The best-approximating model for Pied-billed Grebe $\hat{\psi}$ included pond area, SCI, and cropland. Large ponds with high shoreline complexity and less cropland in the surrounding uplands had the highest occupancy (Table 2, Figs. 1B and 1D). As was the case for Horned Grebe, other plausible models $(\leq 2 \Delta \mathrm{AIC})$ contained variables with slope coefficient $85 \%$ CIs that overlapped 0 , suggesting their effects were negligible. Model-averaged estimates indicated that Pied-billed Grebe $\hat{\Psi}$ was lowest on smaller ponds and estimates rose three-fold as ponds increased in area from 1 to 3 ha (Fig. 1C). Predicting $\hat{\Psi}$ for breeding Pied-billed Grebes on ponds $>2.25$ ha was less precise because of the low number of ponds of this size at our study sites and corresponding wide CIs. However, pond size distributions were consistent with other grebe studies (Fournier and Hines 1999, Osnas 2003). Extent of emergent vegetation was not a good predictor of Pied-billed Grebe occupancy and we obtained no support for a nonlinear relationship. Pond occupancy for Pied-billed Grebe was similar in landscapes with a relatively high density of semipermanent and
Table 1. Model selection results for the Pied-billed (Podilymbus podiceps) and Horned Grebe (Podiceps auritus) detection probabilities $(p)$. All models $\leq 2$ Akaike's Information Criterion (AIC) units of the best-approximating model are reported and are ranked by difference in AIC ( $\triangle \mathrm{AIC})$ from the bestapproximating model. Individual model weights $\left(w_{i}\right)$ and number of parameters $(K)$ are also reported.

\begin{tabular}{|c|c|c|c|}
\hline \multirow[b]{2}{*}{ Model $^{\dagger}$} & \multicolumn{3}{|c|}{ Model } \\
\hline & $\Delta \mathrm{AIC}^{\ddagger}$ & $w_{i}$ & $K$ \\
\hline \multicolumn{4}{|l|}{ Pied-billed Grebe } \\
\hline$p($ Area + Date $), \Psi()$. & 0.00 & 0.07 & 4 \\
\hline$p($ Area + Date + Time $), \Psi()$. & 0.58 & 0.05 & 5 \\
\hline$p($ Area + Cloud + Date $), \Psi()$. & 1.50 & 0.03 & 5 \\
\hline$p($ Area + Date + Temperature $), \Psi()$. & 1.51 & 0.03 & 5 \\
\hline$p($ Area + Date + Wind $), \Psi()$. & 1.55 & 0.03 & 5 \\
\hline$p($ Area $+\mathrm{SCI}+$ Date $), \Psi()$. & 1.83 & 0.03 & 5 \\
\hline$p($ Area + Date + Observer $), \Psi()$. & 1.92 & 0.02 & 5 \\
\hline$p($ Area + Cloud + Date + Time $), \Psi()$. & 1.93 & 0.02 & 6 \\
\hline$p($ Area + Date + Temperature + Time $), \Psi()$. & 1.96 & 0.02 & 6 \\
\hline \multicolumn{4}{|l|}{ Horned Grebe } \\
\hline$p($ Area + Time $), \Psi()$. & 0.00 & 0.02 & 4 \\
\hline$p($ Area + Observer + Time $), \Psi()$. & 0.20 & 0.02 & 5 \\
\hline$p($ Area + SCI + Time $), \Psi()$. & 0.44 & 0.02 & 5 \\
\hline$p($ Area $), \Psi()$. & 0.63 & 0.02 & 3 \\
\hline$p($ Area + Observer $), \Psi()$. & 0.82 & 0.01 & 4 \\
\hline$p(),. \Psi()$. & 1.39 & 0.01 & 2 \\
\hline$p($ Area + SCI + Observer + Time $), \Psi()$. & 1.43 & 0.01 & 6 \\
\hline$p($ Area + EVI $), \Psi()$. & 1.45 & 0.01 & 4 \\
\hline$p($ Area + Time + Wind $), \Psi()$. & 1.52 & 0.01 & 5 \\
\hline$p$ (Time), $\Psi()$. & 1.53 & 0.01 & 3 \\
\hline$p($ Area + EVI + Time $), \Psi()$. & 1.59 & 0.01 & 5 \\
\hline$p($ Area + Temperature + Time $), \Psi()$. & 1.61 & 0.01 & 5 \\
\hline$p($ Area + EVI + Observer $), \Psi()$. & 1.66 & 0.01 & 5 \\
\hline$p($ Area + Observer + Temperature + Time $), \Psi()$. & 1.72 & 0.01 & 6 \\
\hline$p($ Area + EVI + Observer + Time $), \Psi()$. & 1.80 & 0.01 & 6 \\
\hline$p($ Area + SCI $), \Psi()$. & 1.85 & 0.01 & 4 \\
\hline$p($ Area $+\mathrm{SCI}+\mathrm{Time}), \Psi()$. & 1.89 & 0.01 & 6 \\
\hline$p($ Area + Observer + Time + Wind $), \Psi()$. & 1.91 & 0.01 & 6 \\
\hline \multicolumn{4}{|c|}{$\begin{array}{l}{ }^{7} \text { Variables are: wetland area (Area), shoreline complexity index (SCI), } \\
\text { emergent vegetation index in the linear form (EVI), time of day (Time), date } \\
\text { (Date), percent cloud cover (Cloud), wind speed (Wind), and observer } \\
\text { (Observer). }\end{array}$} \\
\hline
\end{tabular}

permanent ponds $(\hat{\Psi}=0.14 \pm 0.06 \mathrm{SE})$ compared to low pond density landscapes $(\hat{\Psi}=0.10 \pm 0.05 \mathrm{SE})$.

\section{Co-occurrence on ponds}

From multiple breeding pair and brood surveys, pairs of both species were detected on three of 172 ponds. Both species were detected on different visits to one small pond ( $0.33 \mathrm{ha})$, yet no brood was observed. The second pond was larger (1.75 ha), both species occurred during the same visit(s), and broods of both species were recorded. The third pond involved a single Horned Grebe observation followed by a Pied-billed Grebe detection. Likewise, co-occurrence of broods was detected only three times.

\section{Productivity}

Overall, adult Horned Grebes were observed on 51 ponds while adult Pied-billed Grebes were observed on 24 ponds. Subsequently, broods were observed on 38 and 16 ponds for Horned and Pied-billed Grebes, respectively, obviating robust 
Table 2. Model selection results for the Pied-billed (Podilymbus podiceps) and Horned Grebe (Podiceps auritus) occupancy estimation $(\Psi)$ relative to habitat and landscape variables ${ }^{\dagger}$. All models $\leq 2$ Akaike's Information Criterion (AIC) units of the best-approximating model are reported and are ranked by difference in AIC ( $\triangle \mathrm{AIC})$ from the best-approximating model. Individual model weights $\left(w_{i}\right)$ and number of parameters $(K)$ are also reported.

\begin{tabular}{|c|c|c|c|}
\hline \multirow[b]{2}{*}{ Model $^{\dagger}$} & \multicolumn{3}{|c|}{ Model } \\
\hline & $\Delta \mathrm{AIC}^{\ddagger}$ & $w_{i}$ & $K$ \\
\hline \multicolumn{4}{|l|}{ Pied-billed grebe } \\
\hline$p($ Area + Date $), \Psi($ Area $+\mathrm{SCI}+$ Cropland $)$ & 0.00 & 0.22 & 7 \\
\hline $\begin{array}{l}p(\text { Area }+ \text { Date }), \Psi(\text { Area }+ \text { EVI }+ \text { SCI + Wetland } \\
\text { density + Cropland })\end{array}$ & 0.74 & 0.15 & 9 \\
\hline$p($ Area + Date $), \Psi($ Area + EVI + SCI + Cropland $)$ & 1.41 & 0.11 & 8 \\
\hline $\begin{array}{l}p(\text { Area + Date }), \Psi(\text { Area }+ \text { EVI + SCI + Wetland } \\
\text { density + Year + Cropland })\end{array}$ & 1.88 & 0.09 & 10 \\
\hline \multicolumn{4}{|l|}{ Horned grebe } \\
\hline$p($ Area + Time $), \Psi(\mathrm{EVI})$ & 0.00 & 0.11 & 5 \\
\hline$p($ Area + Time $), \Psi(\mathrm{EVI}+\mathrm{SCI})$ & 0.10 & 0.11 & 6 \\
\hline$p($ Area + Time $), \Psi($ EVI + Cropland $)$ & 1.57 & 0.05 & 6 \\
\hline$p($ Area + Time $), \Psi($ EVI + SCI + Cropland $)$ & 1.72 & 0.05 & 7 \\
\hline$p($ Area + Time $), \Psi($ EVI + SCI + Year $)$ & 1.73 & 0.05 & 7 \\
\hline$p($ Area + Time $), \Psi($ EVI + Year $)$ & 1.74 & 0.05 & 6 \\
\hline$p($ Area + Time $), \Psi\left(\mathrm{EVI}^{2}\right)$ & 1.86 & 0.04 & 6 \\
\hline$p($ Area + Time $), \Psi($ Area + EVI + SCI $)$ & 1.91 & 0.04 & 7 \\
\hline$p($ Area + Time $), \Psi\left(\mathrm{EVI}^{2}+\mathrm{SCI}\right)$ & 1.91 & 0.04 & 7 \\
\hline$p($ Area + Time $), \Psi($ Area + EVI $)$ & 1.93 & 0.04 & 6 \\
\hline$p($ Area + Time $), \Psi($ EVI + Wetland density $)$ & 1.96 & 0.04 & 6 \\
\hline$p($ Area + Time $), \Psi($ EVI + SCI + Wetland density $)$ & 2.01 & 0.04 & 7 \\
\hline \multicolumn{4}{|c|}{$\begin{array}{l}\text { Variables are: emergent vegetation index in the linear (EVI) and } \\
\text { quadratic }\left(\mathrm{EVI}^{2}\right) \text { forms, shoreline complexity index (SCI), the proportion } \\
\text { of upland within } 100 \mathrm{~m} \text { that is crop (Cropland), wetland area (Area), } \\
\text { wetland density (density of semipermanent and permanent wetlands } \\
\text { within the study site), and Year (either } 2010 \text { or } 2011 \text { ). } \\
\text { Lowest AIC for Pied-billed Grebe }=207.9 \text { and Horned Grebe }=352.0 \text {. }\end{array}$} \\
\hline
\end{tabular}

comparisons of features of ponds with and without broods. The index of breeding success, using naïve occupancy, was similar for Horned (0.75, SE = 0.06) and Pied-billed (0.67, $\mathrm{SE}=0.07)$ Grebes.

Of 53 ponds surveyed in both 2010 and 2011, 15 were used in 2011 by Horned Grebes; however, pond use by breeding birds in 2011 was unrelated to whether $(4 / 13=30.8 \%)$ or not $(11 / 40=$ $27.5 \%$ ) a conspecific brood was detected in 2010 ( $G$-test, $P=0.82$ ). In Pied-billed Grebes, 14 of the 53 ponds were used in 2011 by breeding birds and use was not related to presence of a conspecific brood in 2010 (used: 4/10 $=40 \%$; not used: 10/43 $=23.3 \%$; $G$-test, $P=0.30)$.

\section{DISCUSSION}

Grebe habitat use was related most closely to pond-specific factors rather than those operating at spatial scales beyond the local wetland basin, consistent with previous waterbird research (Naugle et al. 1999). Although there was no observable difference in pond occupancy rates between low and high wetland density landscapes, the latter contributes disproportionately more breeding habitat for grebes. Conservation initiatives that protect habitat for the grebes, particularly the Horned Grebe, should
Fig. 1. Model-averaged occupancy probability (solid line) and $95 \%$ confidence intervals (dashed line) for Pied-billed (Podilymbus podiceps; grey) and Horned (Podiceps auritus; black) Grebes relative to: (A) the emergent vegetation index (EVI), where 0 represents no emergent vegetation and 1 represents no open water; (B) the shoreline complexity index (SCI), where 1 represents a perfectly circular wetland and 2 represents a wetland with a perimeter twice the length than that of a circular wetland with the same area; (C) wetland area (ha); and (D) proportion of the upland comprised of cropland (within $100 \mathrm{~m}$ ).
(A)

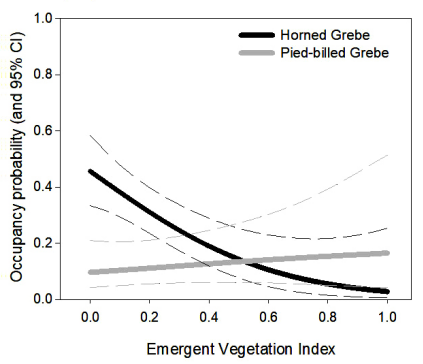

(C)

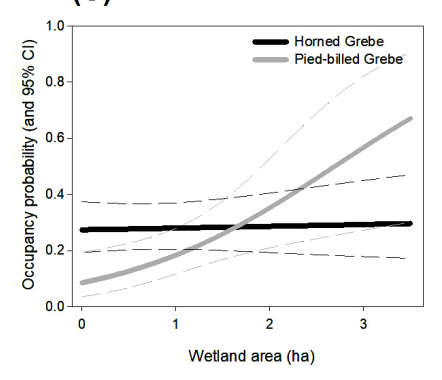

(B)

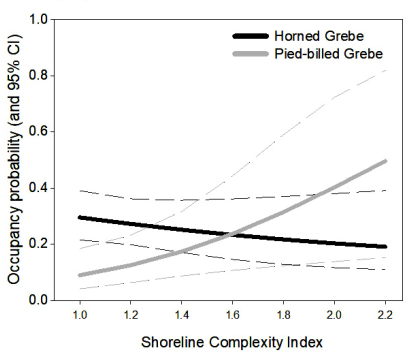

(D)

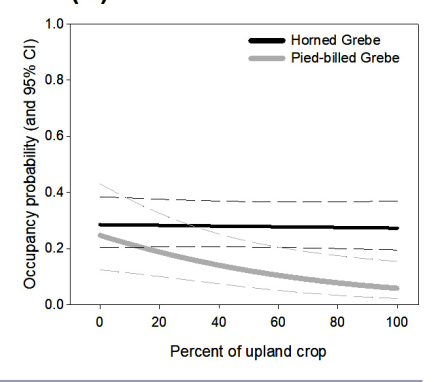

focus on prairie and parkland regions that contain a high density of semipermanent and permanent ponds. Landscapes composed of high densities of wetland basins and breeding ducks are currently being targeted for wetland and upland habitat protection and restoration in the Prairie Pothole Region (PPR) under the North American Waterfowl Management Plan (Humburg et al. 2018), and our findings indicate that grebe species could benefit from these initiatives. Still, most Canadian PPR wetlands occur on private land where individual producers "manage" surface water resources, including ponds. Thus, implementation and periodic review of existing (Alberta) and proposed (Saskatchewan, Manitoba) wetland protection policies are needed to safeguard water supplies for wildlife, and people, across the entire region (Spence et al. 2018).

To our knowledge, this study encompassed the largest overall study area for grebe habitat use in Canada and is the first attempt to simultaneously distinguish habitat use by Horned and Piedbilled Grebes while accounting for imperfect detection. This methodological improvement is important: the habitat occupancy relationships we quantified should be robust because they accounted for the covariates that most influenced our ability to detect grebes. Results confirmed that these grebe species use ponds with different vegetation features, but our findings were not 
consistent with a hypothesis that relationships are nonlinear, e.g., with thresholds or "optima." Horned Grebes occupied ponds with limited emergent vegetation while Pied-billed Grebes occupied larger ponds with greater shoreline complexity, especially ponds located in nonagricultural upland areas. Piedbilled Grebes were less likely to occupy ponds surrounded by cropland, as reported by Saunders et al. (2019). Grebes are often used as indicator species of environmental quality (O'Donnel and Fjeldså 1997) and it is possible that ponds within agriculturally dominated landscapes are more vulnerable to degradation (Bartzen et al. 2010) and, in turn, are not used as often by Piedbilled Grebes. Water quality and macroinvertebrate communities are more likely to be negatively impacted in wetland basins that have little vegetative buffer in the uplands and experience direct agrochemical runoff (Riens et al. 2013, Main et al. 2015).

The occupancy probabilities for Pied-billed and Horned Grebe were relatively low but the detection probability for Pied-billed Grebes was substantially lower than for Horned Grebes, as we reported previously (Routhier et al. 2014). The more secretive behavior of Pied-billed Grebes, even in response to a callbroadcast survey, combined with a preference for larger wetlands with more emergent vegetation and complex shorelines are likely drivers of lower detection probability. Conversely, the higher detection probability for Horned Grebes is likely attributable to their less secretive behavior and active response to the callbroadcast survey while typically occupying smaller, more open wetlands. Horned Grebe detection probabilities were such that allocating additional resources to increase survey intensity, i.e., more than three surveys, would likely not yield increased statistical power, which is particularly important for monitoring initiatives (Steenweg et al. 2019). For species like Pied-billed Grebes, increasing survey frequency and number of sampling units could increase detection probabilities and statistical power (MacKenzie and Royle 2005).

Interspecific competition can influence pond use and Pied-billed Grebes are expected to usurp breeding habitat from Horned Grebes (Osnas 2003). If Pied-billed Grebes forced Horned Grebes into suboptimal breeding habitats, we would expect a comparative reduction in the number of broods hatched by Horned Grebes. However, apparent productivity estimates for Horned Grebes were similar to those observed for Pied-billed Grebes. This may be attributable to differential habitat preferences that allow Horned Grebes to exhibit optimal habitat selection in areas where Pied-billed Grebes also occur. Because the index of breeding success was high in both species, we were unable to explore differences in characteristics of ponds occupied by adults where a brood was subsequently observed versus not detected. Finally, although limited by sample size, there was no indication that either grebe species responded by occupying ponds with previous breeding success more often than ponds with no brood(s) the previous year. Determining whether productive habitat differs from used habitat, i.e., ponds with breeding activity but did not hatch a brood, is important and this idea warrants further investigation. Horned Grebes could experience higher chick mortality in the later growth stages, reducing fledging success, or face carry-over effects of rearing young in suboptimal habitat. We lacked frequent visits to ponds occupied by grebe broods attended by marked parents, and this information would provide estimates of chick survival to fledging and thus better link reproductive success to pond characteristics.
Prairie wetlands undergo periods of drought and inundation (van der Valk and Davis 1978), and our study was conducted when wetland basins were nearing a maximum flood stage due to consecutive years of above-average spring run-off and growing season precipitation, which could influence how grebes are distributed. Furthermore, ponds may be more numerous within $400 \mathrm{~m}$ along roads on WBPHS segments than $800 \mathrm{~m}$ from roads (Austin et al. 2000). The high abundance of semipermanent and permanent ponds may have allowed both species to exhibit optimal habitat use in part by reducing intraspecific and interspecific competition.

Although some previous studies have reported Horned and Piedbilled Grebes using seasonal wetlands during the breeding season (Kantrud and Stewart 1984, Naugle et al. 2001), it is possible that increasing pond water levels and preassigned wetland classifications could explain why we observed no grebes on seasonal wetlands. Surveys conducted during the wet-dry cycle that incorporate behavioral observations of marked grebes and detailed productivity metrics would be ideal. Horned and Piedbilled Grebes have different morphological adaptations for foraging that enable Pied-billed Grebes to capture and consume larger prey items. Relating occupancy patterns to prey type or food availability would also be informative because these factors have been influential in other bird groups (e.g., Hanson and Butler 1994, Benoy 2005). Given the evidence presented here, integrating studies of ponds located in areas of varying upland habitat types (especially cropland) and wetland complexes with trophic research could prove particularly informative (Savard et al. 1994, Boyd et al. 1989).

Responses to this article can be read online at: http://www.ace-eco.org/issues/responses.php/1641

\section{Acknowledgments:}

We are grateful to Steve Leach, Lauren Bortoloti, Chantel Michelson, and Colin McKay for assistance in the field; Environment and Climate Change Canada, University of Saskatchewan, and the Natural Sciences and Engineering Research Council of Canada (Discovery Grant to $R G C$ ) for funding and resources for data collection; and Stantec Consulting Ltd. for providing support to DDR in preparing this manuscript. We thank $J$-P. Savard and two anonymous reviewers for their constructive reviews.

\section{LITERATURE CITED}

Arnold, T. W. 2010. Uninformative parameters and model selection using Akaike's Information Criterion. Journal of Wildlife Management 74:1175-1178. https://doi.org/10.1111/ j.1937-2817.2010.tb01236.x

Austin, J. E., H. T. Sklebar, G. R. Guntenspergen, and T. K. Buhl. 2000. Effects of roadside transect width on waterfowl and wetland estimates. Wetlands 20:660-670. https://doi.org/10.1672/0277-5212 (2000)020[0660:EORTWO]2.0.CO;2

Bartzen, B. A., K. W. Dufour, R. G. Clark, and F. D. Caswell. 2010. Trends in agricultural impact and recovery of wetlands in 
prairie Canada. Ecological Applications 20:525-538. https://doi. org/10.1890/08-1650.1

Benoy, G. A. 2005. Variation in tiger salamander density within prairie potholes affects aquatic bird foraging behaviour. Canadian Journal of Zoology 83:926-934. https://doi.org/10.1139/z05-081

Bock, C. E., and Z. F. Jones. 2004. Avian habitat evaluation: should counting birds count? Frontiers in Ecology and the Environment 2:403-410. https://doi.org/10.1890/1540-9295(2004) 002[0403:ahescb]2.0.co;2

Boyd, W. S., J.-P. L. Savard, and G. E. J. Smith. 1989. Relationship between aquatic birds and wetlands characteristics in the aspen parkland, Central British Columbia. Technical Report Series No. 70. Canadian Wildlife Service, Pacific and Yukon Region, Delta, British Columbia, Canada.

Burnham, K. P., and D. R. Anderson. 2002. Model selection and inference: an information theoretic approach. Second edition. Springer Science, New York, New York, USA.

Clark, R. G., and D. Shutler. 1999. Avian habitat selection: pattern from process in nest-site use by ducks? Ecology 80:272-287. https://doi.org/10.1890/0012-9658(1999)080[0272:AHSPFP]2.0.CO;2

Committee on the Status of Endangered Wildlife in Canada (COSEWIC). 2009. COSEWIC assessment and status report on the Horned Grebe Podiceps auritus Western population and Magdalen Islands population, in Canada. COSEWIC, Ottawa, Ontario, Canada.

Conway, C. J. 2009. Standardized North American marsh bird monitoring protocols. Wildlife Research Report \#2009-02. U.S. Geological Survey, Arizona Cooperative Fish and Wildlife Research Unit, Tucson, Arizona, USA. [online] URL: https:// www.cals.arizona.edu/research/azfwru/NationalMarshBird/downloads/ North $\% 20$ American $\% 20$ Marsh $\% 20$ Bird $\% 20$ Survey $\% 20$ Protocol $\%$ 20May\%202009.pdf

Conway, C. J., and J. P. Gibbs. 2005. Effectiveness of callbroadcast surveys for monitoring marsh birds. Auk 122:26-35. https://doi.org/10.1093/auk/122.1.26

Conway, C. J., and C. P. Nadeau. 2010. Effects of broadcasting conspecific and heterospecific calls on detection of marsh birds in North America. Wetlands 30:358-368. https://doi.org/10.1007/ s13157-010-0030-1

Devries, J. H., R. G. Clark, and L. Armstrong. 2018. Dynamics of habitat selection in birds: adaptive response to nest predation depends on multiple factors. Oecologia 187:305-318. https://doi. org/10.1007/s00442-018-4134-2

Environmental Systems Research Institute (ESRI). 2011. ArcGIS Desktop: Release 10. ESRI, Redlands, California, USA.

Ettema, C. H., and D. A. Wardle. 2002. Spatial soil ecology. Trends in Ecology and Evolution 17:177-183. https://doi.org/10.1016/ S0169-5347(02)02496-5

Faaborg, J. 1976. Habitat selection and territorial behavior of the small grebes of North Dakota. Wilson Bulletin 88:390-399.

Fairbairn, S. E., and J. J. Dinsmore. 2001. Local and landscapelevel influences on wetland bird communities of the prairie pothole region of Iowa, USA. Wetlands 21:41-47. https://doi. org/10.1672/0277-5212(2001)021[0041:LALLIO]2.0.CO;2
Ferguson, R. S. 1977. Adaptations of the Horned Grebe for breeding in prairie pothole marshes. Thesis. University of Manitoba, Winnipeg, Manitoba, Canada.

Ferguson, R. S., and S. G. Sealy. 1983. Breeding ecology of the Horned Grebe, Podiceps auritus, in southwestern Manitoba. Canadian Field-Naturalist 97:401-408.

Fiske, I., and R. Chandler. 2011. unmarked: an R package for fitting hierarchical models of wildlife occurrence and abundance. Journal of Statistical Software 43:1-23. https://doi.org/10.18637/ jss.v043.i10

Fournier, M. A., and J. E. Hines. 1999. Breeding ecology of the Horned Grebe Podiceps auritus in subarctic wetlands. Occasional Paper No. 99. Canadian Wildlife Service, Ottawa, Ontario, Canada.

Fretwell, S. D., and H. L. Lucas. 1969. On the behavior and other factors influencing habitat distribution in birds. I. Theoretical development. Acta Biotheoretica 19:16-36. https://doi.org/10.1007/ BF01601953

Gibbs, J. P., and S. M. Melvin. 1993. Call-response surveys for monitoring breeding waterbirds. Journal of Wildlife Management 57:27-34. https://doi.org/10.2307/3808996

Government of Canada. 2020. Species at risk public registry. Government of Canada, Ottawa, Ontario, Canada. [online] URL: https://www.canada.ca/en/environment-climate-change/ services/species-risk-public-registry.html

Hammell, G. 2017. Changes to the population status of Horned Grebes (Podiceps auritus) and Red-necked Grebes (Podiceps grisegena) in southwestern Manitoba, Canada. Canadian FieldNaturalist 131:317-324. https://doi.org/10.22621/cfn.v131i4.2069

Hanson, M. A., and M. G. Butler. 1994. Responses to food web manipulation in a shallow waterfowl lake. Pages 457-466 in J. J. Kerekes, editor. Aquatic birds in the trophic web of lakes. Developments in Hydrobiology book series. Springer, Dordrecht, The Netherlands. https://doi.org/10.1007/978-94-011-1128-7_42

Humburg, D. D., M. G. Anderson, M. G. Brasher, M. F. Carter, J. M. Eadie, D. C. Fulton, F. A. Johnson, M. C. Runge, and M. P. Vrtiska. 2018. Implementing the 2012 North American Waterfowl Management Plan Revision: populations, habitat, and people. Journal of Wildlife Management 82:275-286. https://doi. org/10.1002/jwmg.21391

Jedlikowski, J., P. Chibowski, T. Karasek, and M. Brambilla. 2016. Multi-scale habitat selection in highly territorial bird species: exploring the contribution of nest, territory and landscape levels to site choice in breeding rallids (Aves: Rallidae). Acta Oecologica 73:10-20. https://doi.org/10.1016/j.actao.2016.02.003

Kantrud, H. A., and R. E. Stewart. 1984. Ecological distribution and crude density of breeding birds on prairie wetlands. Journal of Wildlife Management 48:426-437. https://doi.org/10.2307/3801174

Krebs, C. J. 1994. Ecology: the experimental analysis of distribution and abundance. Fourth edition. Harper Collins, New York, New York, USA.

Kuczynski, E. C., C. A. Paszkowski, and B. A. Gingras. 2012. Horned Grebe habitat use of constructed wetlands in Alberta, 
Canada. Journal of Wildlife Management 76:1694-1702. https:// doi.org/10.1002/jwmg.421

MacKenzie, D. I., J. D. Nichols, G. B. Lachman, S. Droege, J. A. Royle, and C. A. Langtimm. 2002. Estimating site occupancy rates when detection probability rates are less than one. Ecology 83:2248-2255. https://doi.org/10.1890/0012-9658(2002)083[2248: ESORWD]2.0.CO;2

MacKenzie, D. I., J. D. Nichols, J. A. Royle, K. H. Pollock, L. L. Bailey, and J. E. Hines. 2006. Occupancy estimation and modeling: inferring patterns and dynamics of species occurrence. Elsevier, San Diego, California, USA.

MacKenzie, D. I., and J. A. Royle. 2005. Designing occupancy studies: general advice and allocating survey effort. Journal of Applied Ecology 42:1105-1114. https://doi.org/10.1111/ j.1365-2664.2005.01098.x

Main, A. R., N. L. Michel, J. V. Headley, K. M. Peru, and C. A. Morrissey. 2015. Ecological and landscape drivers of neonicotinoid insecticide detections and concentrations in Canada's Prairie Wetlands. Environmental Science and Technology 49:8367-8376. https://doi.org/10.1021/acs.est.5b01287

McGarigal, K., and B. J. Marks. 1995. FRAGSTATS: spatial pattern analysis program for quantifying landscape structure. General Technical Report PNW-GTR-351, U.S. Forest Service, Pacific Northwest Research Station, Portland, Oregon, USA. https://doi.org/10.2737/PNW-GTR-351

McGarigal, K., H. Y. Wan, K. A. Zeller, B. C. Timm, and S. A. Cushman. 2016. Multi-scale habitat selection modeling: a review and outlook. Landscape Ecology 31:1161:1175. https://doi. org/10.1007/s10980-016-0374-X

Naugle, D. E., K. F. Higgins, S. M. Nusser, and W. C. Johnson. 1999. Scale-dependent habitat use in three species of prairie wetland birds. Landscape Ecology 14:267-276. https://doi. org/10.1023/A:1008088429081

Naugle, D. E., R. R. Johnson, M. E. Estey, and K. F. Higgins. 2001. A landscape approach to conserving wetland bird habitat in prairie pothole region of eastern South Dakota. Wetlands 21:1-17. https://doi.org/10.1672/0277-5212(2001)021[0001:ALATCW] 2.0.CO;2

Nudds, T. D. 1982. Ecological separation of grebes and coots: interference competition or microhabitat selection? Wilson Bulletin 94:505-514.

O'Donnell, C., and J. Fjeldså. 1997. Grebes: status survey and conservation action plan. IUCN/SSC Grebe Specialist Group, Cambridge, UK.

Osnas, E. E. 2003. The role of competition and local habitat conditions for determining occupancy patterns in grebes. Waterbirds 26:209-216. https://doi.org/10.1675/1524-4695(2003) 026[0209:TROCAL]2.0.CO;2

Otto, J. E. 1983. Breeding ecology of the Pied-billed Grebe (Podilymbus podiceps [Linnaeus]) on Rush Lake, Winnebago County, Wisconsin. Thesis. University of Wisconsin, Oshkosh, Wisconsin, USA.
R Development Core Team. 2014. R: A language and environment for statistical computing. Version 3.10. R Foundation for Statistical Computing, Vienna, Austria. [online] URL: http:// www.R-project.org.

Riens, J. R., M. S. Schwarz, F. Mustafa, and W. W. Hoback. 2013. Aquatic macroinvertebrate communities and water quality at buffered and non-buffered wetland sites on federal waterfowl production areas in the Rainwater Basin, Nebraska. Wetlands 33:1025-1036. https://doi.org/10.1007/s13157-013-0460-7

Routhier, D. D. 2012. Spatiotemporal variation in occupancy and productivity of grebes in prairie Canada: estimation and conservation applications. Thesis. University of Saskatchewan, Saskatoon, Canada.

Routhier, D. D., K. W. Dufour, M. T. Bidwell, and R. G. Clark. 2014. Surveying populations of breeding grebes in prairie parkland Canada: estimation problems and conservation applications. Wildlife Society Bulletin 38:14-17. https://doi. org/10.1002/wsb.362

Saunders, S. P, K. A. L. Hall, N. Hill, and N. L. Michel. 2019. Multiscale effects of wetland availability and matrix composition on wetland breeding birds in Minnesota, USA. Condor 121(3): duz024. https://doi.org/10.1093/condor/duz024

Savard, J.-P. L., S. W. Boyd, and G. E. J. Smith. 1994. Waterfowlwetland relationships in the Aspen parkland of British Columbia: comparison of analytical methods. Pages 309-325 in J. J. Kerekes, editor. Aquatic birds in the trophic web of lakes. Developments in Hydrobiology book series. Springer, Dordrecht, The Netherlands. https://doi.org/10.1007/978-94-011-1128-7_29

Sealy, S. G. 1978. Clutch size and nest placement of the Pied-billed Grebe in Manitoba. Wilson Bulletin 90:301-302.

Shutler, D., A. Mullie, and R. G. Clark. 2000. Bird communities of prairie uplands and wetlands in relation to farming practices in Saskatchewan. Conservation Biology 14:1441-1451. https://doi. org/10.1046/j.1523-1739.2000.98246.x

Smith, G. W. 1995. A critical review of the aerial and ground surveys of breeding waterfowl in North America. Biological Science Report 5, National Biological Service, Washington, D.C., USA.

Spence, C., J. D. Wolfe, C. J. Whitfield, H. M. Baulch, N. B. Basu, A. K. Bedard-Haughn, K. W. Belcher, R. G. Clark, G. A. Ferguson, M. G. Hayashi, K. Liber, J. J. McDonnell, C. A. Morrissey, J. W. Pomeroy, M. G. Reed, and G. Strickert. 2018. Prairie water: a global water futures project to enhance the resilience of prairie communities through sustainable water management. Canadian Water Resources Journal 44:115-126. https://doi.org/10.1080/07011784.2018.1527256

Steenweg, R., M. Hebblewhite, J. Whittington, and K. McKelvey. 2019. Species-specific differences in detection and occupancy probabilities help drive ability to detect trends in occupancy. Ecosphere 10:e2639. https://doi.org/10.1002/ecs2.2639

Stewart, R. E., and H. A. Kantrud. 1971. Classification of natural ponds and lakes in the glaciated prairie region. Resource Publication 92, Bureau of Sport Fisheries and Wildlife, U.S. Fish and Wildlife Service, Washington, D.C., USA. 
Sugden, L. G. 1977. Horned Grebe breeding habitat in Saskatchewan parklands. Canadian Field-Naturalist 91:372-376.

Tozer, D. C., E. Nol, and K. F. Abraham. 2010. Effects of landscape-scale habitat variables on abundance and reproductive success of wetland birds. Wetland Ecology and Management 18:679-693. https://doi.org/10.1007/s11273-010-9187-x

U.S. Fish and Wildlife Service and Canadian Wildlife Service. 1987. Standard operating procedures for aerial waterfowl breeding ground population and habitat surveys in North America. U.S. Department of the Interior, Fish and Wildlife Service, Washington, D.C., USA, and Environment Canada, Canadian Wildlife Service, Ottawa, Ontario, Canada.

van der Valk, A. G., and B. C. Davis. 1978. The role of seed banks in the vegetative dynamics of prairie glacial marshes. Ecology 59:322-335. https://doi.org/10.2307/1936377

Van Horne, B. 1983. Density as a misleading indicator of habitat quality. Journal of Wildlife Management 47:893-901. https://doi. org/10.2307/3808148

Vickery, P. D., M. L. Hunter, and J. V. Wells. 1992. Is density an indicator of breeding success? Auk 109:706-710. https://doi. org/10.2307/4088146

Wrubleski, D. A., and L. C. M. Ross. 2011. Aquatic invertebrates of prairie wetlands: community composition, ecological roles, and impacts of agriculture. Pages 91-116 in K. D. Floate, editor. Arthropods of Canadian grasslands (Volume 2): inhabitants of a changing landscape. Biological Survey of Canada, Ottawa, Ontario, Canada.

Editor-in-Chief: Alexander L.Bond Subject Editor: Jean-Pierre L.Savard
Sponsored by the Society of Canadian Ornithologists and Birds Canada

Parrainée par la Société des ornithologistes du Canada et Oiseaux Canada

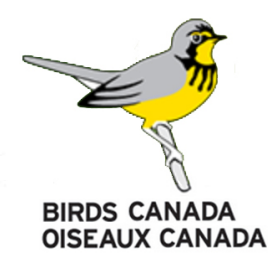

